\title{
"Barking Men, Speaking Dogs: Animalisation of Human Beings in Pinter's Mountain Language and Bakhtyar Ali's the Death of the Second Only Son"
}

\author{
Zanyar Faiq Saeed \\ $\mathrm{PhD}$ in English Literature \\ English Department, School of Languages \\ Faculty of the Humanities, University of Sulaimani \\ zanyar.saeed@univsul.edu.iq
}

\begin{abstract}
No totalitarian regime can rule for a long time without oppression. One of the worst and most common strategies designed by such regimes to prolong their life is to create a force void of any humanitarian concerns. Two of the most crucial characteristics that distinguish human beings from other creatures are thinking and feeling. Without them, a human being could be turned into an object, a machine or, dangerously, into a beast. This paper entitled "Barking Men, Speaking Dogs: Animalisation of Human Beings in Pinter's Mountain Language and Bakhtyar Ali's The Death of the Second Only Son" studies the theme of animalisation, i.e., how some people trained to be brutal creatures are ready to torture, injure, and kill in cold blood anyone who protests against the regime.
\end{abstract}

Keywords: totalitarian regimes, animalisation, Pinter, Mountain Language, Bakhtyar Ali, Death of the Second Only Son

\section{INTRODUCTION}

Literature has often been considered a mirror reflecting life. Since politics is an important and effective aspect of life, it has occupied a considerable part of the literary world as well. This is much truer to modern/postmodern life and literature. One of the twentieth-century authors whose life and literature were highly politically engaged is Harold Pinter. Pinter himself "insists[s] that his art has always been political ..." (Stokes 227). His Mountain Language could be considered one of the most openly political plays (Aragay i Sastre 17). It depicts the brutality exercised by totalitarian regimes represented by their officials who have lost their humanity and have been turned into vicious animals. Bakhtyar Ali, likewise, is politically engaged in his life and literature as well. In his articles, poems and novels, he portrays the suffering of the Kurds from successive Iraqi regimes and even from the current Kurdish authority. In his novella, The Death of the Second Only Son (1997), he depicts the authority as a brutal lecherous animal persecuting people. Hence, the title of this paper, "Barking Men, Speaking Dogs: Animalisation of Human Beings in Pinter's Mountain Language and Bakhtyar Ali's The Death of the Second Only Son". The paper claims that Pinter and Ali demonstrate that human beings can be turned by totalitarian regimes into beasts that are ready to kill in cold blood. Throughout history, these animalized forces have been one of the most important factors behind the survival of totalitarian regimes. All such regimes have such a force that is ready, without thinking and feeling, to execute any order. A natural human being could be prevented by his/her thinking and feeling from acting brutally and cruelly; but a person deprived of them will torture and kill ferociously. This paper demonstrates how Pinter and Ali expose these animalized human beings and the authority they protect; it also displays the savage deeds resulting from such process of animalization. Understanding this theme will make readers much more conscious of this bestially dehumanizing process; this will, in turn, prevent them from being victims and/or victimizers.

\section{Mountain Language}

"Every dog has a name!"

Though, originally, Mountain Language (1988) was inspired by the predicament of the Kurds in Turkey, it is written to have a universal appeal. Describing the play, Pinter asserts that: 
[Mountain Language] remains brutal, short and ugly.

[It] lasts only 20 minutes, but it could go on for hour after hour, on and on and on, the same pattern repeated over and over again, on and on, hour after hour.

Farhood confirms that the totalitarian regimes are the source of this brutality, "The sense of ... terror is dominant [in the play] to intensify the presentation of the great suffering of the victims in totalitarian regimes" (13). Thus, the play depicts totalitarian brutality and how it is sustained within the same regime and throughout history. It tells the story of a group of women who have come to visit their imprisoned men (sons, brothers, husbands). These women and men are called mountain people. Absurdly, their only crime is that they speak in their native language. Throughout the four short scenes, the playwright shows how the Officer and the Sergeant, representative of the authority, torture these women and men physically and verbally as Kane confirms, “... in ... Mountain Language, Pinter depicts physical and psychological torture, erotic sadism, and human rights abuses" (2). $\mathrm{He}$ provides examples of the cruel acts, committed against these women and men, as effects of the process of animalization. In the first scene, he establishes this fact, i.e., that the Officer, the Sergeant and the guards have been turned into beasts. Chiasson asserts that Mountain Language performs a "...violent, chaotic and ... untamable action ..." (123). The word untamable describes these animalized human beings and their uncontrollable behaviour.

Feeling and thinking are the two most dangerous enemies of totalitarian regimes. No totalitarian regime can survive without turning their people into feeling-less and thinking-less creatures. Though they fail to turn all the people into such creatures, they succeed in turning some. Some strategies that such regimes may use to animalize people are poverty, hunger, brainwashing, etc.

When the Officer asks if the women, waiting to see their imprisoned men, have any complaints, the Young Woman answers, "She's [the Elderly woman] been bitten." (Pinter 6). When the play opens, the Elderly Woman is discovered cradling her bitten hand. The image usually associated with "biting" is that of an animal. Accordingly, readers expect that an animal has bitten her.

The Officer seems to be concerned about what has happened to the Elderly Woman; he asks, "What's happened to your hand? Has someone bitten your hand?" (Pinter 6). The indefinite pronoun someone confuses the readers' previous perception of the image of an animal, i.e., the Officer does not ask about an animal which has bitten her, but about a person. In an answering gesture, the Elderly Woman lifts her hand and shows it to the Officer. Again the latter asks, "Who did this?" Who bit you?" (Pinter 6). Farhood (11) believes that the Officer's insistence on knowing the name of the dog confirms the absurdity of the situation. Though his is a tenable argument, this paper interprets the situation in a different way. Using who, instead of which, changes the image in readers' mind from that of an animal into that of a human being.

However, the Young Woman's answer, "a Dobermann pinscher" (Pinter 6), confuses readers yet more. This is because the name that she provides in answering who is the name of a dog, not of a human being. This answer does not satisfy the Officer because he wants to know exactly which (or who) among the Dobermann pinschers has bitten the Elderly Woman:

OFFICER: Which one?

Pause.

Which one?

Pause.

Sergeant!

SERGEANT steps forward.

SERGEANT: Sir!

OFFICER: Look at this woman's hand. I think the thumb is going to come off. (To ELDERLY WOMAN) Who did this?

She stares at him 
Who did this?

YOUNG WOMAN: a big dog.

OFFICER: What was his name?

Pause.

(Pinter 7)

When the Young Woman describes the Dobermann pinscher as a big dog, the Officer seems to have lost his patience. That is why he clearly asks to know the identity of that dog. Using the personal possessive pronoun his is in line with the other stylistically important uses of someone and who. They all refer to human beings. Moreover, asking about the name of the dog is also significant, though at first it may seem quite normal for dogs to have names. Still the image in readers' mind is a blurred one: is it the image of an animal given some human characteristics or that of a human being turned into an animal? The following paragraphs discuss which question is more valid.

The pause after the Officer's last question shows that no one has answered him. That is why the officer repeats the same question stressing the word name, "What was his name?" (Pinter 8). Graphologically, the word name is italicized for emphasis. This emphasis indicates that the second question is more valid than the first one. As the Officer does not get an answer, he explains to the women:

Every dog has a name! They answer to their name. They are given a name by their parents and that is their name that is their name! Before they bite, they state their name. It's a formal procedure. They state their name and then they bite. What was his name? If you tell me one of our dogs bit this woman without giving his name I will have that dog shot! (Pinter 8)

In many ways, this passage is of prime importance. It is normal to give a dog a name, but it is not normal for every dog to have a name. This proves that the word $d o g$ is used to describe behaviour, rather than to name a species. The author again stresses this idea by italicizing the word name. Even if dogs have a name, it is given to them by their owners; but the Officer says that that name is given to them by their parents: no one has ever heard of a father- or mother-dog giving name to his/her children. As the Officer states, when they are called upon by their names, they answer; this means that each $\operatorname{dog}$ has a name that distinguishes it from the others and they themselves know this.

The Officer describes this act of calling out names and answering as a formal procedure. Actually, this is a familiar military procedure: calling out soldiers' name, answering to their name, asking permission before acting, and if they break the rules, they will be punished (or shot). It is obvious that these do not apply to dogs. The Officer says that before the dogs bite, they "state their name"; the verb state is italicized to emphasize the act of stating; that is, mentioning one's name. Even if a dog has a name, it cannot state its name. The act of stating its name is not a simple one; it is complex and involves many other activities; it means that the dog thinks about doing something; it plans to implement it; it knows that there is a system governing its actions; that is why it decides to take permission; therefore, it states its name in order to be allowed to act; finally, it acts. Only human beings have these faculties. The last sentence in the quotation above shows that what the Officer means by dog is not really a dog, but a human being turned into a dog. Shooting a dog because of not mentioning its name before doing something is quite ridiculous, if taken literally. However, for a human being turned into an obedient dog to act without permission is quite unacceptable, especially in a totalitarian regime. That is why the Officer promises to shoot him.

Pinter has often stated that totalitarian regimes, and even seemingly democratic governments, are bloodthirsty wild animals (qtd. in Ward). These animalized human beings are the shield of the authority. They are pitilessly brutal. Pinter affirms this fact saying, "in ... Mountain Language, there are brutal, brutal, brutal forces." (Interview by Cusac) and "Mountain Language is a series of brutal images" (Interview by Billington). His repetition of the word brutal indicates that the brutality practised by the authority in Mountain Language is inexpressible; it is so monstrous that language fails to understand, explain and communicate it. The four scenes are portrayals of torture and humiliation. When the play opens, a line of women, who have been waiting in the snow for eight hours to see their imprisoned men, is seen. Among them is an Elderly woman whose hand has been bitten by a dog (animalized man); she is bleeding and her thumb is about to come off. Though she suffers, the Officer neglects her and tries to know the dog/man that has bitten her without taking 
permission and has broken the rules. In another case, The Sergeant and Officer abuse the Young Woman whose husband has been arrested because he was mistakenly considered a mountain man. They abuse her verbally and physically; they circle her, touch her bottom and ask what language she speaks with her "arse" (Pinter 10). Another example is the Young Woman's husband who has been tortured to death though he is not from the mountain. The situation may continue incessantly. These are just a few examples of the brutal act of the animalised human beings. Prentice confirms that Mountain Language is "the bleakest, most pitiless, and remorseless of Pinter's plays" (285).

\section{The Death of The SECONd ONLY SON}

"I am turning, bit by bit, into a hound."

Bakhtyar Ali was born in Sulaimani City-Iraq in 1960. He is an intellect, a poet, and a novelist. In the beginning of $1980 \mathrm{~s}$, he participated in a university students' protest against the Ba'th regime. As a result, he was severely wounded and arrested for a period. Because of his continuous political activity, he was arrested again by the Ba'th regime. In 1983, he went to Iran in order to travel to a western country but he came back to Sulaimani and lived the life of a military fugitive. In 1994, upset because of the Kurdish Civil War, he went abroad and now he lives in Germany (Ra'uf 30). His novella, The Death of the Second Only Son, was written in 1986, revised in 1987 and published in 1997.

The novella tells the story of the enigmatic death of Ashraf, the protagonist. The setting of the novella is Sulaimani when the Kurds in North Iraq were living under the subsequent totalitarian regimes, though this is not openly stated. One of the important themes in the novella is the animalization of human beings. Throughout the novella, the author presents many images of how inhumanly and brutally the government officials treat the ordinary people.

One of the major characters in the novella is Sarhung. He, the most powerful official in the city, is dreaded by all. The following passage is a conversation between him and another character, a boy:

My lord Sarhung, why are you so thin, what makes you so confused and thin?

"My son, life is dishonest; nobody knows when it will blow its fucking arse's wind into our noses. Even a dog cannot endure all that labour. Look at me; I am turning, bit by bit, into a hound." My lord Sarhung, how like a hound you are! You with your long legs look so much like a hound. When he took his feet out of his shoes, ... he had the claws of a wild hound ... Oh, lord Sarhung, why don't you try to cure yourself? "Nay, my son, don't hurry; one day, you will see all those living in this mansion will turn into hounds from their navel down." The boy was thinking about that day in which the men of the mansion will drag their hound legs through porches, roofs, cellars, and restaurants, unaware that they have caught Sarhung's disease. (Ali 50-51)

This passage is of great importance because it clearly shows how the most powerful official, Sarhung, is turned into a brutal hunting creature. He is the emblem of torturing and murdering in cold blood. As he himself says, his disease is contagious and one day all his men will turn into hunting creatures. These men, who will be animalized unknowingly, will spread all through the city and persecute people without thinking and feeling.

In another place, when an officer comes to investigate Ashraf's death, the narrator describes him and his men as follows:

My God, what a bad dog he was; when standing near the [Ashraf's] corpse, he was covering his mouth with a handkerchief, as if standing near a pile of shit. He was followed by an army of dummy guards, who, after Mustafa Khoshnow's rebellion, were being given a special drug to prevent them from thinking. (Ali 42-43)

Mustafa Khoshnow (?-1949) was a Kurdish politician and military officer in the Iraqi army. He participated in the 1943-1945 Kurdish revolt in Iraq led by Mustafa al-Barzani. In 1945 when the uprising collapsed, he escaped with the Barzanis to Iran. There, he helped form the Mahabad Republic's army and led it in a battle against the Iranian army. Upon his return to Iraq, he was accused of treason and executed in Baghdad in 1949 (Ghareeb 136). There are some key words related to the theme of animalisation in the passage above; one of them is the word $d o g$, which the narrator uses to describe the officer; it reminds readers of those turned into hounds. Two other key words are rebellion and thinking. The narrator explains that after Khoshnow rebelled against the government, the authority gave the soldiers/guards/troops a kind of medicine that made them unable 
to think. This resulted in "an army of dummy guards". The only function of this army is to follow orders without thinking and feeling. "Do, then discuss" was a very famous dictum, especially in the army corps, during the Ba'th rule in Iraq. This order, which leaves no space for the freedom of action, renders the act of discussing absurd because discussion must logically precede doing. In the passage above, the author wants to confirm that thinking led Khoshnow to rebel; that is why the authority tries to render its men thoughtless because thinking is a dangerous enemy.

The second most powerful person after Sarhung is Saeed Sultan Bey. Saeed and Ashraf are maternal brothers. They are their mother's only two sons. Saeed is described as the first only son and Ashraf as the second because they are from different fathers. Throughout the novella, whenever Saeed appears, he is followed by hounds. In the passage below, one of the narrators describes Saeed and his hounds:

He [Saeed] was the leader of those hounds ... an army of hounds ... they were the same army of hounds that were, in the evenings, loosed in the vegetable venders market, running between the legs of the workers, jumping over carts; they were the same hounds which were dispersing queues at bakeries, leaping over the heads of bread-sellers, and no one could hurt them. ... Grandma [Saeed and Ashraf's mother], with my own naked eyes, I saw the hounds chasing the butterflies that were flying under the lantern light; they wanted to attack something, anything. Three-day hunger was enraging them, rendering them impatient. Because of that hunger, Saeed Sultan Bey's fingers were dragging them like magnetics. (Ali 17)

The above passage is a practical example of what has been said before that the hounds will move freely in the city and persecute people. It reminds readers of the boy's vision when he heard Sarhung talking about men turning to hounds. It also shows the intimate relationship between Saeed and his hounds. Saeed's power of guiding the hounds is compared to the gravitating power of magnetics; an attracting power that has been created by keeping the hounds hungry for days. This passage demonstrates one of the major strategies dictatorial regimes adopt to make people follow their orders without feeling and thinking, i.e., famishing. The quotation below provides more explanation of Saeed and his hounds:

That day, he [Saeed] was looking just for Ashraf, but the hungry hounds were seeking to cut anyone into pieces. They did not care about who the person was or what his name was. The pleasure that he was getting from murdering Ashraf, they were getting it from killing anyone. Gosh, they were uncountable. ... Surely, Grandma, he was speaking with the hounds in a language that we never know, understand or learn; he had told them "Go, be free ... go ... may this night by your happy night." (Ali 18)

The complex utterance Saeed uses to speak with his hounds proves that they understand what he has said, process it mentally and then act accordingly. That is why they move freely everywhere and no one can stop them. This is evidence that these are not real hounds, they are human beings turned into animals. These animal-humans are so submissive to Saeed and love him so much (because they are famished) that they are ready even to kill his girlfriend; she narrates to Grandma how he forced her to go with him:

With his homicidal hands, he dragged me. He didn't want the hounds to see me. He was murmuring, not sure whether he was supplicating or swearing; he was saying to me, "I hate these hounds, I don't want them to see you ... I don't." He was afraid that, out of their loyalty for him, they may assault me. (Ali 30)

Another significant point is the hounds' act of watching that disturbs Saeed. If they were really hounds, he would not have cared whether they watch him when he is with her or not. However, because they are human beings, their looks are purposive and expose Saeed and his immoral behaviour. Hence, he hates them.

When Ashraf's funeral has been prepared in Grandma's castle, his brother, Saeed, comes with his hounds. One of the narrators describes the situation thus:

When the orchestra of that crying was rising from every corner and room, we sensed the sudden and untimely scent of those hounds accompanying Saeed Sultan like a storm and entering through windows, doors, roofs, and cellars....

It seemed that the smell of that death annoyed them and reminded them of the last night's memory. (Ali 89) 


\section{Zanyar Faiq Saeed}

One of the most important faculties that distinguish human beings from other species is that human beings can remember what happened in the past. The quotation above says that when the hounds come to Ashraf's funeral, they become disturbed by the smell of Ashraf's death because it reminds them of what they did the night before. This proves that these are some of those who have been turned into animals as Sarhung has predicted. When Saeed pretends to be very sad and threatens to avenge his brother's murder, a friend of Ashraf shouts, "You wicked murderer [Saeed], move your filthy hounds away from the corpse's way." (Ali 95) The narrator says that "When hearing their names, all the hounds rose to their feet as if awakened by an overall electrical current." (Ali 95). That the hounds are cognizant that they are called by the name hound is evidence that they are really not animals; rather, they are human beings who have been turned into hounds.

After Ashraf's friend's shout, many men follow suit and raise their voice; they revolt against Saeed, his hounds and Sarhung. The revolt separates Saeed from his hounds that escape in different directions. Though Saeed moves his staff in the air and screams, his screams do not reach his hounds.

Another important feature assigned the hounds is "remorse". The narrator recounts, "but his shouts could not reach the hounds, which had been scared by the sudden explosion of that anger and ran away barking strangely and remorsefully" Ali ). Only human beings have that inner pricking part called conscience; however, the narrator says that Saeed's hounds run and bark regretfully. This strengthens the claim that these are not hounds, but human beings turned into hounds. Among this fuss, Saeed disappears strangely and nobody knows how and whither.

After a while, the angry mob is attacked by hundreds of "rabid" armed men (Ali 100-101). The adjective rabid used to describe these armed men reminds readers of the hounds, i.e., of a rabid hungry army that does not think and feel; it just follows orders. As one of the narrators says, the uprising people begin to run away in every direction to hide themselves from the army; but wherever they go, they find the rabid army in front of them, "... they were themselves, Saeed Sultan Bey and tens of tall and black-mustached armed men." (Ali 101). Since hounds are known to have a long slender body and long legs, describing the armed men as tall with black mustache reminds readers of the hounds which have run from the angry mob and of Sarhung's long and thin legs, too. Directly after this description the narrator says "but the hounds they brought to find us and their friends, the wounded and lost hounds, caught us." (Ali 101) This is another point to prove the claim that the hounds are actually human beings because after describing the armed men as tall and blackmustached, the narrator uses the name hounds to refer to them. Also importantly, these hounds have come to find their wounded friends; their friends are the same hounds which were chased by the revolting mob. Perhaps, the best proof that these hounds are not literal ones, but human beings acting as hounds is the author's speech; Ali himself confirmed this in a personal interview with the researcher:

RESEARCHER: I believe that the hounds in your novella are actually human beings turned into hounds, in the same way as the dogs in Pinter's Mountain Language.

ALI: Yes, quite right.

RESEARCHER: How can a human being be turned into an animal?

ALI: By the authority; by deforming a person's character; by changing him into a creature which cannot think; by famishing him so much that he would do something that he does not like or intend. The process of the animalisation of human beings is continuous in our world. A human being becomes an object forgetting his conscience, selling his moral and political affiliation, sometimes for bread, sometimes for money, sometimes for anything. It is a constant process in our reality. In The Death of the Second Only Son, (and you are the first to notice this fact) the hounds are really human beings and are not different from the human authority. (Personal)

It is clear from Ali's statement that he deliberately depicts the authority as hounds so as to expose their brutality, cruelty, and pitilessness.

\section{Conclusion}

In conclusion, it is now clear that Pinter and Ali demonstrate the theme of the animalization of human beings by totalitarian regimes. Both show how human beings can be turned into merciless wild animals. They are concerned about this dangerous issue of reducing human beings into only some animalistic drives. This fact must make people conscious and intellectually aware in order not to become victims of such regimes and victimize their own people in turn. 


\section{REFERENCES}

Ali, Bakhtyar. Personal interview. 1 April, 2011. Audiotape.

Ali, Bakhtyar. The Death of the Second Only Son. Sulaimani: Karo, 2009. [The extracts are translated from Kurdish into English by the researcher].

Aragay i Sastre, Mireia. "Political Pinter: Mountain Language in Context." Bells: Barcelona English language and literature studies. Vol. 2 (1990): 17-29.

Chiasson, Basil Alexander Eugene. "Harold Pinter and the Performance of Power: Considerations of Affect in Select Plays, Screenplays and Films, Poetry and Political Speeches." Diss. U of Leeds, 2010.

Farhood, Abbas Hilal. "Political Suppression and Cruelty: A Study in Harold Pinter's One for the Road and Mountain Language." Al-Mustansiriyah University Journal 54 (2011): 1-25.

Ghareeb, Edmund A. Historical Dictionary of Iraq. Oxford: Scarecrow Press, 2004.

Kane, Leslie. The Art of Crime: The Plays and Films of Harold Pinter and David Mamet. New York: Routledge, 2004.

Pinter, Harold. "Art, Truth and Politics: The Nobel Lecture." Route-online. 2006

Pinter, Harold. Interview by Anne-Marie Cusac. "Harold Pinter interviews".

http://www.progressive.org/mag/pinter.html. Accessed 30 Nov., 2015

Pinter, Harold. Interview by Michael Billington.

http://www.theguardian.com/education/2001/jun/30/arts.highereducation. Accessed 28 Dec., 2015.

Pinter, Harold. Mountain Language. London: Faber and Faber, 2001.

Prentice, Penelope. The Pinter Ethic: The Erotic Aesthetic. New York: Garland Publishing, 2000.

Ra'uf, Alan. "Le gel Baxtiyar Elîda: Bašî Yekem [With Bakhtyar Ali: Part One]." Khak 94 (2005): 3035 .

Stokes, John. "Pinter's late tapes". The Cambridge Companion to Harold Pinter. Ed. Peter Raby. Cambridge: CUP, 2009. 216-229.

Ward, Ian. Law, Text, Terror. Cambridge: CUP, 2009.

\section{AUTHOR'S BIOGRAPHY}

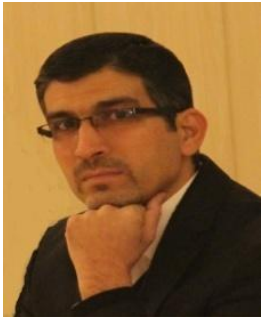

Dr. Zanyar Faiq Saeed, Ph.D. in English Literature, has been teaching in the English Department, School of Languages, University of Sulaimani-Iraq since 2001. Generally, he is interested in literature particularly in drama. He has peerreviewed academic journal articles. He participated in many MA discussions. He has translated some books from English into Kurdish. He writes poetry in Kurdish, Arabic and English. 